\title{
wiiw
}

Wiener Institut für

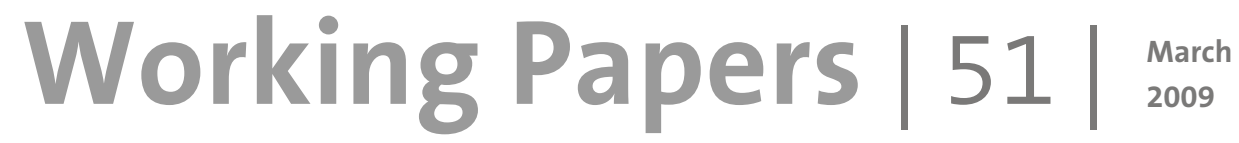

Piero Esposito and Robert Stehrer

\section{Effects of High-Tech Capital, FDI and Outsourcing on Demand for Skills in West and East}




\section{wiiw Working Papers published since 2000:}

No. 51 P. Esposito and R. Stehrer: Effects of High-Tech Capital, FDI and Outsourcing on Demand for Skills in West and East. March 2009

No. 50 C. Fillat-Castejón, J. F. Francois and J. Wörz: Cross-Border Trade and FDI in Services. February 2009

No. 49 L. Podkaminer: Real Convergence and Inflation: Long-Term Tendency vs. Short-Term Performance. December 2008

No. 48 C. Bellak, M. Leibrecht and R. Stehrer: The Role of Public Policy in Closing Foreign Direct Investment Gaps: An Empirical Analysis. October 2008

No. 47 N. Foster and R. Stehrer: Sectoral Productivity, Density and Agglomeration in the Wider Europe. September 2008

No. 46 A. lara: Skill Diffusion by Temporary Migration? Returns to Western European Work Experience in Central and East European Countries. July 2008

No. 45 K. Laski: Do Increased Private Saving Rates Spur Economic Growth? September 2007

No. 44 R. C. Feenstra: Globalization and Its Impact on Labour. July 2007

No. 43 P. Esposito and R. Stehrer: The Sector Bias of Skill-biased Technical Change and the Rising Skill Premium in Transition Economies. May 2007

No. 42 A. Bhaduri: On the Dynamics of Profit- and Wage-led Growth. March 2007

No. $41 \quad$ M. Landesmann and R. Stehrer: Goodwin's Structural Economic Dynamics: Modelling Schumpeterian and Keynesian Insights. October 2006

No. 40 E. Christie and M. Holzner: What Explains Tax Evasion? An Empirical Assessment based on European Data. June 2006

No. 39 R. Römisch and M. Leibrecht: An Alternative Formulation of the Devereux-Griffith Effective Average Tax Rates for International Investment. May 2006

No. 38 C. F. Castejón and J. Wörz: Good or Bad? The Influence of FDI on Output Growth. An industry-level analysis. April 2006

No. 37 J. Francois and J. Wörz: Rags in the High Rent District: The Evolution of Quota Rents in Textiles and Clothing. January 2006

No. $36 \quad$ N. Foster and R. Stehrer: Modelling GDP in CEECs Using Smooth Transitions. December 2005

No. 35 R. Stehrer: The Effects of Factor- and Sector-biased Technical Change Revisited. September 2005

No. 34 V. Astrov, Sectoral Productivity, Demand, and Terms of Trade: What Drives the Real Appreciation of the East European Currencies? April 2005

No. 33 K. Laski: Macroeconomics versus 'Common Sense'. December 2004

No. 32 A. Hildebrandt and J. Wörz: Determinants of Industrial Location Patterns in CEECs. November 2004

No. $31 \quad$ M. Landesmann and R. Stehrer: Income Distribution, Technical Change and the Dynamics of International Economic Integration. September 2004

No. 30 R. Stehrer: Can Trade Explain the Sector Bias of Skill-biased Technical Change? May 2004

No. 29 U. Dulleck, N. Foster, R. Stehrer and J. Wörz: Dimensions of Quality Upgrading in CEECs. April 2004

No. 28 L. Podkaminer: Assessing the Demand for Food in Europe by the Year 2010. March 2004

No. 27 M. Landesmann and R. Stehrer: Modelling International Economic Integration: Patterns of Catching-up, Foreign Direct Investment and Migration Flows. March 2004

No. 26 M. Landesmann and R. Stehrer: Global Growth Processes: Technology Diffusion, Catching-up and Effective Demand. January 2004

No. 25 J. Wörz: Skill Intensity in Foreign Trade and Economic Growth. November 2003; revised version January 2004

No. 24 E. Christie: Foreign Direct investment in Southeast Europe: a Gravity Model Approach. March 2003

No. 23 R. Stehrer and J. Wörz: Industrial Diversity, Trade Patterns and Productivity Convergence. November 2002; revised version July 2003

No. 22 M. Landesmann and R. Stehrer: Technical Change, Effective Demand and Economic Growth. April 2002

No. 21 E. Christie: Potential Trade in South-East Europe: A Gravity Model Approach. March 2002

No. 20 M. Landesmann, R. Stehrer and S. Leitner: Trade Liberalization and Labour Markets: Perspective from OECD Economies. October 2001

No. 19 R. Stehrer and J. Wörz: Technological Convergence and Trade Patterns. October 2001

No. 18 R. Stehrer: Expenditure Levels, Prices and Consumption Patterns in a Cross-Section of Countries. August 2001

No. 17 P. Egger and R. Stehrer: International Outsourcing and the Skill-Specific Wage Bill in Eastern Europe. July 2001

No. 16 K. Laski and R. Römisch: Growth and Savings in USA and Japan. July 2001

No. 15 R. Stehrer: Industrial Specialization, Trade, and Labour Market Dynamics in a Multisectoral Model of Technological Progress. January 2001; revised version February 2002

No. 14 M. Landesmann and R. Stehrer: Potential Switchovers in Comparative Advantage: Patterns of Industrial Convergence. June 2000

No. 13 F. Turnovec: A Leontief-type Model of Ownership Structures. Methodology and Implications. April 2000

No. 12 K. Laski: Three Ways to ... High Unemployment. January 2000 
Piero Esposito is a researcher at the Institute for Economic Studies and Analyses, Rome, Italy. Robert Stehrer is Senior Economist at the Vienna Institute for International Economic Studies (wiiw).

Paper written for the project 'Productivity in the European Union: A Comparative Industry Approach (EU KLEMS)', funded by the European Commission, Research Directorate General, as part of the Sixth Framework Programme, Priority 8, 'Policy Support and Anticipating Scientific and Technological Needs', Project 502049.

Piero Esposito and Robert Stehrer

Effects of High-Tech Capital, FDI and Outsourcing on Demand for Skills in West and East 



\section{Contents}

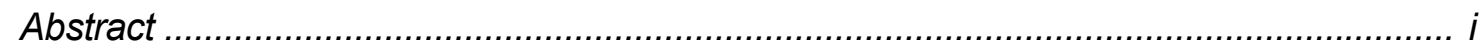

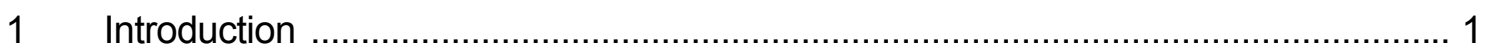

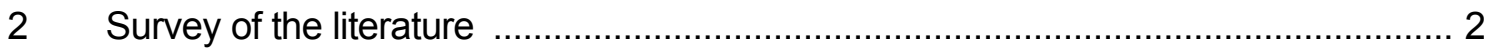

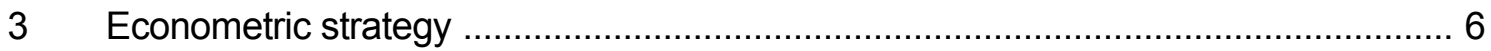

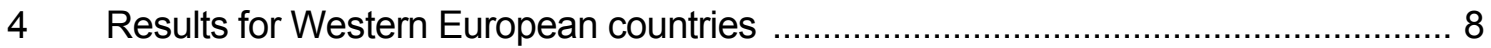

$5 \quad$ Results for Central and Eastern European countries ......................................... 13

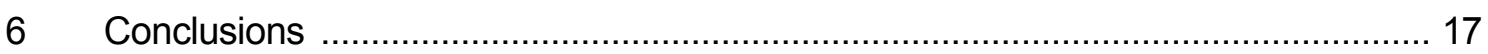

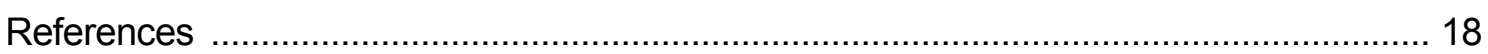




\section{List of Tables}

Table 1 Specification 1: Western European countries .............................................

Table 2 Specification 2: Western European countries ...............................................10

Table 3 Specification 3: Western European countries ..............................................11

Table 4 Specification 1: Central and Eastern European countries ..............................13

Table 5 Specification 2: Central and Eastern European countries ...............................14

Table 6 Specification 3: Central and Eastern European countries .................................15 


\begin{abstract}
In this paper we study the effects of high-tech capital, foreign direct investment flows and outsourcing on demand for labour differentiated by educational attainment levels in the manufacturing industries for two groups of countries over the period 1995-2004. These two groups of countries comprise Western and Eastern European countries respectively which are assumed to be differently affected by the European integration process. Using detailed trade data as a basis for measuring outsourcing we further distinguish the effects of trade and outsourcing on relative wages by different groups of partner countries. This allows to study the effects of 'inward' outsourcing and foreign direct investment flows to Central and Eastern European countries (which became quite important in this time) in the Western European countries and - conversely - to study the effects of 'outward' outsourcing and the increase in inward FDI stocks in the Central and Eastern European countries separately.
\end{abstract}

Keywords: high-tech capital, outsourcing, foreign direct investment, demand for skills

JEL classification: F15, F16, C23 



\section{Effects of High-Tech Capital, FDI, and Outsourcing on Demand FOR Skills in West AND EAST}

\section{Introduction}

The changing patterns of relative demand for skills and for workers differentiated by level of educational attainment have attracted a lot of attention in recent years and the debate is far from closed. Changes in relative demand for workers with a high level of education (and to a lesser extent for those with a medium level of education) have been observed either in terms of rising employment shares and/or in terms of rising skill premia. In the literature various causes are discussed for explaining these trends. First, increased competition with low-income countries was a matter of concern. This was triggered off in the US by the NAFTA agreement and the resulting trade liberalization with Mexico as a low income neighboring country. In Europe the debate started when the Central and Eastern European countries were integrated into the European division of labor after their transitional recessions. Similarly to the US, Western European countries were facing competition from neighboring low-income countries; differently however from the US-Mexico case these countries were generally well endowed with skilled labor and could also build on a strong manufacturing base. Despite these facts the fear was that trade integration with the Central and Eastern European economies would lead to a relative decrease of demand for low-skill workers in the West due to imports of low-skill intensive final products and outsourcing (i.e. imports of intermediate products) of low-skill intensive production stages. Important studies analyzing the employment effects of these developments are summarized in Section 2. There is however much less literature studying the effects on low-income countries, in particular the Central and Eastern European countries. This is somewhat surprising as final goods imports and 'inward outsourcing', i.e. imports of intermediates from the viewpoint of the Western European economies, have its counterparts as final goods exports and 'outward outsourcing, i.e. the exports of these intermediate products, from the viewpoint of the lowerincome Central and Eastern European economies. ${ }^{1}$ To our knowledge there is no attempt in the literature to study the effects of the fragmentation of production for both types of economies in Europe simultaneously drawing on the same database. ${ }^{2}$ This will be the main challenge in this paper.

Similar arguments hold for the effects of foreign direct investment (FDI). Whereas for the Central and Eastern European countries it is mainly the effects of inward FDI on employment that

\footnotetext{
${ }^{1}$ In this sense we refer to 'outsourcing' as international outsourcing, i.e. international fragmentation of production. 'Inward outsourcing' then means the purchase of intermediate products from abroad (imports) whereas 'outward outsourcing' means the selling of intermediate products abroad (exports).

${ }^{2}$ However, evidence on employment effects on both the US and Mexico do exist. There is also some literature pointing towards common trends of rising skill premia in both high and low income countries.
} 
should matter, it was the effects of outward FDI from the viewpoint of the Western economies which was the subject of greater attention. Thus we also include measures for outward and inward FDI stocks in our specifications.

A second main cause for the rising relative demand for skilled workers and the rising skill premia have been seen in the effects of skill-biased technical change driven by capital-skill complementarity and the impact of ICT capital on relative demand patterns. In our empirical work we thus also include capital measures to control for these effects.

In this paper we therefore analyze the effects of (high-tech) capital, FDI flows and fragmentation of production on employment patterns in the Western and Eastern European countries. The first group of countries is seen as being characterized by outward foreign direct investment (i.e. investing abroad where one of the most important target regions in this period have been the Central and Eastern European countries) and 'inward outsourcing'. On the opposite side, the latter group of countries is mainly seen as being the recipient of foreign direct investment (i.e. the importance of inward FDI is a matter of concern) and being the exporters of intermediate products ('outward outsourcing'). This distinction will be taken into account in the particular econometric specifications for both types of economies.

The paper is structured as follows. We proceed with a short survey of the theoretical and empirical literature. Then we give a short discussion of the data we use and the econometric specifications we have chosen. Sections 4 and 5 then report some results for the group of Western and Eastern European countries respectively. Section 6 concludes.

\section{Survey of the literature}

Following the political debate on the fear that globalization would cause job losses in the advanced economies, the issue of outsourcing started to gain importance in the theoretical literature at the begin of the 1990s, with the seminal contribution of Jones and Kierzkowski (1990). They argue that international outsourcing increased in the recent years thanks to the technological development of service activities linking production processes taking place in different countries.

The effects of the fragmentation of production on factor prices have been investigated theoretically in a variety of models. This has shown that the expected effects depend very much on specific assumptions on the relative factor intensity of the outsourced production stage, the sector in which outsourcing takes place, etc. Further, the effects depend very much on whether one takes a general equilibrium approach as opposed to analyzing the effects for a single industry. For example Arndt (1997) uses a $2 \times 2 \times 2$ Heckscher-Ohlin framework and shows that in the typical situation, in which both the skill-abundant and the skill-scarce country engage in reciprocal outsourcing of the fragment using the scarce factor relatively more intensively, this leads to an 
increase in both wages and employment of unskilled workers in comparison with skilled labor. ${ }^{3}$ This simple result is, in any case, at odds with the empirical evidence of rising skill premium and skill intensity in both skill and unskilled labor-abundant countries.

A number of papers analyzed fragmentation in a more general framework (see Deardorff, 1998, 2001; Jones and Kierzkowski, 2001; Kohler, 2001, 2004). Deardorff (2001) shows that cost-saving fragmentation occurs only when countries lie on different "cones of diversification", exploiting factor price differences due to lack of factor price equalization. In a different work the same author argues that fragmentation can foster factor price equalization (Deardorff, 1998). Hence, there is no clear direction of change in factor prices when countries engage in outsourcing. The direction of the effect depends on the interplay between the factor intensities in the overall production of the two countries and on that of the industry fragmenting the production (see also Kohler, 2001, 2004, for discussion based on specific-factors model). In general, effects on the relative factor prices may emerge when the difference between the skill intensity of the outsourced fragment and a country's average skill intensity is high. Feenstra and Hanson (1997) use a model with a single good produced with a continuum of stages with different skill intensities to show the effect of FDI on the skill premium of both sourcing and outsourcing countries. In this context, outsourcing from a skill-abundant country via FDI can induce a skill-biased effect on the production of the receiving country even when the outsourced fragment is labor intensive. The skill-biased effect will take place when the average skill intensity of the receiving country is lower than that of the outsourced fragment. The authors then provide empirical evidence of the skill-biased impact of FDI in the case of Mexico's maquilladoras.

The issue of outsourcing has been more deeply investigated by the same authors in Feenstra and Hanson (1999), where the authors develop a two-stage econometric procedure for endogenizing TFP and estimate the impact of outsourcing on the skill premium. Further, they develop two measures of outsourcing which has become the main reference for empirical works on the subject: narrow outsourcing, defined as the sum of imported intermediate inputs in one industry from the same industry, and broad outsourcing, which considers imported inputs purchased in one industry from all industries. Within this framework they find that outsourcing explains between $15 \%$ and $40 \%$ of the increase in the relative wage of non-production workers, while high-technology capital explains between $35 \%$ and $70 \%$.

Following the contribution by Feenstra and Hanson (1997) empirical work has focused on the skill-biased impact of outsourcing on both old and new members of the European Union. In the first group the most relevant studies concentrate on larger countries, especially the UK (Anderson and Brenton, 1999; Hijzen, 2007; Hijzen et al., 2005) and Germany (Helg and Tajoli, 2005; Geishecker, 2006) or bordering countries like Austria (Lorentowicz et al., 2005; Marin, 2004).

\footnotetext{
${ }^{3}$ In his paper Arndt considers capital instead of skilled labor but the same results apply when considering skilled labor instead of capital.
} 
Hijzen (2007) and Hijzen et al. (2005) investigate the impact of outsourcing and technological change on the skill structure of both wages and employment in the British manufacturing. Hijzen (2007) estimates the impact on wages by applying the narrow and broad measure of outsourcing defined above and by separating the factor-bias effect from that of the sector bias. The result is that for wages both skill-biased technical change and outsourcing increased inequalities by reducing the wage of unskilled workers, but the effect of the latter is lower. Further, the sectorbias impact of outsourcing is 3.5 times higher than its factor-bias impact. Similar results arise for the labor demand effect (Hijzen et al., 2005), with narrow outsourcing driving down the demand for unskilled labor and $\mathrm{R} \& \mathrm{D}$ increasing the demand for skills. Hence, both factors contributed substantially to the skill upgrading in British industry.

Helg and Tajoli (2005) investigate the impact of outward processing on both relative employment and relative wages of skilled workers in Italy and Germany. Their main finding is that international outsourcing contributed significantly to the increase of the skilled to unskilled labor ratio in Italy, but not in Germany. According to the authors, this puzzling result is due to the specialization of Italy into traditional low-skill-intensive industries, while in Germany the industries most engaged in fragmentation have a higher skill intensity. Hence, in the former the difference in factor intensity between the outsourced fragment and the country's average is higher, causing a strong impact on labor demand, while in Germany the factor intensities of the domestic and outsourced productions are similar, causing little or no labor demand effects. ${ }^{4} \mathrm{~A}$ recent analysis by Geishecker (2006) on the German case came to different conclusions. Specifically, the author's finding is that outsourcing to CEECs contributed significantly to the reduction of the relative demand for unskilled labor, while total outsourcing had a much lower impact. The difference between the two results lies mainly in the separation between outsourcing to CEECs and outsourcing to the rest of the World, with the former accounting for most of the impact. Nevertheless, problems with the specification and the econometrics probably influenced the results. In his regressions Geishecker uses both the broad and narrow measures of outsourcing as suggested by Feenstra and Hanson, while Helg and Tajoli consider only trade in intermediate inputs collected from the Eurostat COMEXT database. In addition, the former addresses the problem of endogeneity of the outsourcing measures, which is likely to return biased estimates due to inconsistency, hence the results of Geishecker are more reliable, both in terms of specification and in terms of the estimation procedure. In Austria, the outsourcing process worked in a way similar to the Italian case. Recent studies (Lorentowicz et al., 2005; Marin, 2004, 2006) provide evidence that Austria is specializing in low-skill stages of the production chain while outsourcing high-skill production stages, reducing as a consequence the share of skilled labor in production costs.

Considering Eastern European countries, the majority of the studies investigated the impact

\footnotetext{
${ }^{4} \mathrm{~A}$ similar results with a different methodology is that of Marin (2004).
} 
of FDI on the relative demand for skilled labor proxied by non-manual workers (Bruno et al., 2004; Lorentowicz et al., 2005; Skuratowicz, 2001; Kertesi and Köllö, 2002). Due to the lack of data, most of the studies use a panel of industries and document a skill-biased impact of foreign capital in the Czech Republic, Hungary and Poland (see Kertesi and Köllö, 2002; Bruno et al., 2004; Lorentowicz et al., 2005). An exception to this methodology is the paper of Skuratowicz (2001) which uses regional data for Poland and finds that FDI increases the skill premium within each region but exacerbates differences between regions, increasing the geographical polarization of inequalities. Lacking data from input-output tables, the outsourcing process has been specifically investigated in a number of papers by using trade in intermediates as proxy for it (Egger and Stehrer, 2003; Egger, 2006; Geishecker, 2004; Kaminski and Ng, 2005; Marin, 2006; Esposito, 2007). What comes out from these contributions is that in the early stages of the transition process outsourcing from Western to Eastern Europe induced the latter group of countries to specialize in the production and export of unskilled labor-intensive intermediates (Egger and Stehrer, 2003) and in assembling activities (Kaminski and Ng, 2005). In particular (Egger and Stehrer, 2003) using a panel of 3 countries and 14 industries found that both importing and exporting of intermediates move the wage-bill-ratio in favor of manual workers. The latter impact is stronger for intermediate exports, suggesting a relative specialization in elementary goods from raw materials. With the same data Egger (2006) found that outsourcing fostered a factor-price equalization among Central and Eastern European industries with the variation of wages being reduced more strongly among skilled workers than among unskilled workers.

From the end of the 1990s, as found by Kaminski and Ng (2005), the New Member States' integration into the EU-based network of production increased enormously and changed the countries' specialization towards the production and export of parts and other outsourcingrelated products. Recent studies on outsourcing and demand for skilled and unskilled labor in Central and Eastern European countries report both skilled- and unskilled-biased impacts of intermediate goods trade (Geishecker, 2004; Esposito, 2007). Geishecker (2004) investigated the impact of FDI and trade in intermediate and final commodities on the demand for high-, mediumand low-skilled labor. Using a large panel of industries for seven Central and Eastern European countries he found, first, that imported intermediate goods from the EU15 to these countries increased the demand for the high-skilled; second, that the same variable, together with the FDI stock, exerted an opposite impact on the demand for medium-skilled labour, while there was no significant impact for the low-skilled. The impact of exported intermediates was also found to be insignificant. Esposito (2007) further divides intermediate goods into parts and components and primary and processed commodities and uses a 14-industry panel to estimate the determinants of the evolution of the skilled to unskilled (non manual to manual) wage bill ratio in the Czech Republic, Hungary and Poland separately. The general result is that exported intermediates reduce the skill-specific wage gap, with a stronger impact for parts and components and a lower 
(in the polish case opposite) impact of processed commodities. Imported intermediates increase the wage gap in Hungary and reduce it in Poland. In both cases most of the impact comes from imported parts and components. In the Czech Republic only imported processed goods increase the relative wage bill ratio. These impacts are re-estimated in two sub-samples of lowand high-skill-intensive industries and the results indicate that in Hungary, and to a lesser extent in Poland, the positive impact of the outsourcing measures is concentrated in the skill-intensive branches, while the unskilled-biased impact is stronger in the low-skill intensive ones. For the Czech Republic, the results indicate an opposite concentration of the impacts of trade and FDI. ${ }^{5}$ As we pointed out above, this overall pattern is the result of different delocalization strategies on the part of Western European countries.

In this work we investigate the impact of outsourcing and capital goods on two groups of Western and Eastern European countries by conducting estimations on a dynamic panel of industries and countries over time. The main innovation in this is first of all to exploit the newly available data collected by the EU KLEMS project. In particular, we can estimate the determinants of the changes in the wage bill share of the three categories of high-, mediumand low-education workers. Further, we are able to include among the determinants of the skill composition of the wage bill also the capital stock and the share of ICT capital. The latter variable is commonly assumed in the literature to have a skill-biased effect by fostering a skillbiased technical change and, to our knowledge, this determinant has not yet been investigated for the Central and Eastern European countries in this context. For the outsourcing process and FDI flows we use standard proxies given by different measures of intermediate trade intensity, as discussed below.

\section{Econometric strategy}

In order to estimate the impact of the different types of capital, of FDI and of the outsourcing process we split the sample into two subgroups of Western and Eastern European countries. The first group includes Austria, Finland, France, Germany, the Netherlands and the UK; the second one includes the Czech Republic, Hungary and Slovenia. The data allows us to include ten industries. ${ }^{6}$ Outsourcing is measured using trade in intermediate products using data from the UN COMTRADE database and BEC codes. FDI data are collected from the OECD IDI database and the wiiw database on foreign direct investment. Other data are taken from the EU KLEMS database. ${ }^{7}$ The period covered is 1995-2004. In the econometrics we employ a dynamic

\footnotetext{
${ }^{5}$ These results are in line with the finding of Esposito and Stehrer (2007) about the concentration of skill-biased technical change in skill-intensive industries.

${ }^{6}$ We consider NACE industries DA, DB, DD and DE, DF, DG, DH, DJ, DK, DL, and DM. Missing are industries DC, DI, DN mainly due to a lack of FDI data.

${ }^{7}$ In particular capital stock data refer to capital services.
} 
specification given as

$\omega_{j c t}=\rho \omega_{j c t-1}+\alpha_{1} k o r_{j c t}+\alpha_{2} k i c t_{j c t}+\alpha_{3} o_{0 u t} s_{L j c t-1}+\alpha_{4}$ oouts $s_{L j c t-1}+\alpha_{5} f d i i s_{j c t}+\alpha_{5} f d i o s_{j c t}+\varepsilon_{j c t}$

for the Western and

$$
\omega_{j c t}=\rho \omega_{j c t-1}+\alpha_{1} k_{o r} r_{j c t}+\alpha_{2} k i c t_{j c t}+\alpha_{3} \text { outs }_{H j c t-1}+\alpha_{4} \text { oouts } s_{H c t-1}+\alpha_{5} f d i i s_{j c t}+\varepsilon_{j c t}
$$

for the Eastern European countries. Subscript $j$ refers to the industry, $c$ to the country and $t$ to time; $\omega_{j c t}$ is alternatively the share of high-, medium- and low-skilled labor in the total wage bill; kor is the capital-output ratio, kict is the share of ICT in total capital, fdiis and fdios denote the inward and outward stocks of FDI respectively. outs and oouts are the measures of inward and outward outsourcing.

We employ different measures for inward and outward outsourcing. As inward outsourcing measures we use imported intermediate inputs (III), that is, the import of processed commodities and parts and components. The first measure is the share of III in total output, the second and third measures represent the same share in total intermediate inputs and in intermediate inputs of materials respectively. For the outward outsourcing measure we simply use the share of exported intermediates (EII) in total output. In order to better capture the impact of outsourcing we further divide trade variables into trade with high- and low-income countries. A significant impact on the skill structure of employment is expected the more the trading countries differ in their level of income or factor endowments. For this reason we include outward and inward outsourcing to low-income countries in equation (3.1) while in equation (3.2) we include outward and inward outsourcing to high-income countries.

In the specification for Western European countries we include both inward and outward FDI stock because we assume that these countries delocalize production stages to low-income countries via foreign direct investment flows and that, at the same time, they receive FDI from other high-income countries both for delocalization and for market-seeking purposes. However, the Central and Eastern European countries have mainly been targeted for delocalization from advanced (and mainly Western European) countries while their investment abroad is of very low importance over this period. Hence for this second group we include only the inward FDI stock.

For both kor and kict we expect to have a skill-biased effect, therefore we should expect these variables to impact positively on the high skilled or negatively on the low-skilled. By the same token a similar impact is expected for FDI ( fdiis) in Central and Eastern European countries if FDI is mainly cost-driven. Further, if high-income countries delocalize unskilled labor intensive stages of production, a similar impact should be expected for the outward FDI stock ( fdios) in this group.

Turning to the outsourcing variables, we should expect, if anything, a skill-favoring impact of both inward and outward outsourcing in the Western European countries. The reason for this 
is that inward outsourcing replaces unskilled workers whereas outward outsourcing is in favor of skilled workers. For the Central and Eastern European countries, both the theoretical literature and the former empirical results (see Egger and Stehrer, 2003; Esposito, 2007, for example) would suggest that exported intermediates to high-income countries should favor unskilled labor. Previous evidence is mixed for the impact of intermediate imports in these countries; we therefore do not make any a priori assumption on their impact.

Concerning the econometric procedure, the use of a dynamic panel specification is justified by the presence of adjustment costs in labor demand and by the presence of serial correlation in the residuals from a static regression. Because of the availability of FDI data we have an unbalanced panel of industries and countries for the years 1996 to 2004, which is a relatively short time span. Accordingly, for the estimation procedure, we use a System General Methods of Moments (GMM) estimator, which solves the endogeneity problem in dynamic panels by using both a level and difference equation and by instrumenting the endogenous variable with its lagged levels in the difference equation and using lagged differences for the equation in levels (see Arellano and Bover, 1995). This procedure is particularly suited for short, persistent panels and is more efficient than a difference GMM à la Arellano and Bond (Arellano and Bond, 1991) because in the latter, the lagged levels are in general weak instruments. The choice of the instruments and the other econometric details are discussed separately for each group of countries to which we turn in the following sections.

\section{Results for Western European countries}

For the sample of Western European countries we estimated equation (3.1) by adding a full set of time dummies. The presence of serial correlation and the rejection of both the Sargan and Hansen tests forced us to use the lagged levels of the outsourcing measures as internal instruments for the levels equation only. Additional instruments are a time trend and the second lag of value added, which we treat as exogenous. For the equation in first-differences we used the third and fourth lag of the dependent variable, collapsed into a vector, and lags four and five of the capital and FDI measures. For the regression on the low-skilled we excluded from the instruments both value added and the time trend. Further, we used lags two and three of the FDI measures and only lag three of the capital measures. In the specifications we also allowed for a small sample correction (see Windmeijer, 2005). Results are reported in Tables 1 to 3. These specifications with respect to the outsourcing measure (i.e. imported intermediate inputs) used (see above). With these instruments the overidentifying restriction are valid and there is no second order serial correlation.

In all three specification there is a high and significant persistence with the lagged dependent variable being 0.85 for both medium- and low-educated, while for the high-educated it is 0.52 . 


\begin{tabular}{|c|c|c|c|c|c|c|}
\hline \multirow{2}{*}{$\begin{array}{l}\text { Dependent variable: } \\
\text { Wage bill share }_{t-1}\end{array}$} & \multicolumn{2}{|c|}{ high educated } & \multicolumn{2}{|c|}{$\begin{array}{l}\text { Wage-bill share of } \\
\text { medium educated }\end{array}$} & \multicolumn{2}{|c|}{ low educated } \\
\hline & $\begin{array}{r}0.523 \\
(0.000)\end{array}$ & *** & $\begin{array}{r}0.853 \\
(0.000)\end{array}$ & $* * *$ & $\begin{array}{r}0.851 \\
(0.000)\end{array}$ & $* * *$ \\
\hline Capital-output ratio & $\begin{array}{r}0.314 \\
(0.023)\end{array}$ & $* *$ & $\begin{array}{r}-0.344 \\
(0.076)\end{array}$ & * & $\begin{array}{r}0.173 \\
(0.161)\end{array}$ & \\
\hline Share of ICT capital & $\begin{array}{c}-0.133 \\
(0.227)\end{array}$ & & $\begin{array}{r}0.127 \\
(0.132)\end{array}$ & & $\begin{array}{r}0.080 \\
(0.177)\end{array}$ & \\
\hline FDI inward stock share & $\begin{array}{c}-0.003 \\
(0.727)\end{array}$ & & $\begin{array}{r}0.009 \\
(0.390)\end{array}$ & & $\begin{array}{r}0.002 \\
(0.314)\end{array}$ & \\
\hline FDI outward stock share & $\begin{array}{r}0.006 \\
(0.433)\end{array}$ & & $\begin{array}{r}0.035 \\
(0.087)\end{array}$ & * & $\begin{array}{c}-0.042 \\
(0.003)\end{array}$ & $* * *$ \\
\hline Share of III low in total output & $\begin{array}{r}-0.203 \\
(0.003)\end{array}$ & $* * *$ & $\begin{array}{r}0.079 \\
(0.218)\end{array}$ & & $\begin{array}{r}-0.314 \\
(0.021)\end{array}$ & ** \\
\hline Share of EII low in total output & $\begin{array}{r}-0.345 \\
(0.456)\end{array}$ & & $\begin{array}{r}0.136 \\
(0.687)\end{array}$ & & $\begin{array}{c}-0.689 \\
(0.139)\end{array}$ & \\
\hline Constant & $\begin{array}{r}10.359 \\
(0.000)\end{array}$ & *** & $\begin{array}{r}8.403 \\
(0.313)\end{array}$ & & $\begin{array}{r}8.754 \\
(0.019) \\
\end{array}$ & ** \\
\hline Observations & 396 & & 396 & & 447 & \\
\hline Arellano-Bond test for $\operatorname{AR}(1): z=$ & $\begin{array}{l}-2.957 \\
(0.003)\end{array}$ & *** & $\begin{array}{c}-3.723 \\
(0.000)\end{array}$ & *** & $\begin{array}{c}-2.231 \\
(0.026)\end{array}$ & ** \\
\hline Arellano-Bond test for $\operatorname{AR}(2): z=$ & $\begin{array}{r}-0.747 \\
(0.455)\end{array}$ & & $\begin{array}{r}0.842 \\
(0.400)\end{array}$ & & $\begin{array}{r}0.603 \\
(0.547)\end{array}$ & \\
\hline $\begin{array}{l}\text { Sargan test: } \chi_{d f}^{2} \\
\quad \text { df }\end{array}$ & $\begin{array}{r}21.098 \\
26 \\
(0.737)\end{array}$ & & $\begin{array}{r}28.373 \\
26 \\
(0.340)\end{array}$ & & $\begin{array}{r}0.273 \\
27 \\
(1.000)\end{array}$ & \\
\hline $\begin{array}{l}\text { Hansen test: } \chi_{d f}^{2} \\
\quad \text { df }\end{array}$ & $\begin{array}{r}31.686 \\
26 \\
(0.204)\end{array}$ & & $\begin{array}{r}28.594 \\
26 \\
(0.330)\end{array}$ & & $\begin{array}{r}24.613 \\
27 \\
(0.596)\end{array}$ & \\
\hline
\end{tabular}

Table 1: Specification 1: Western European countries 


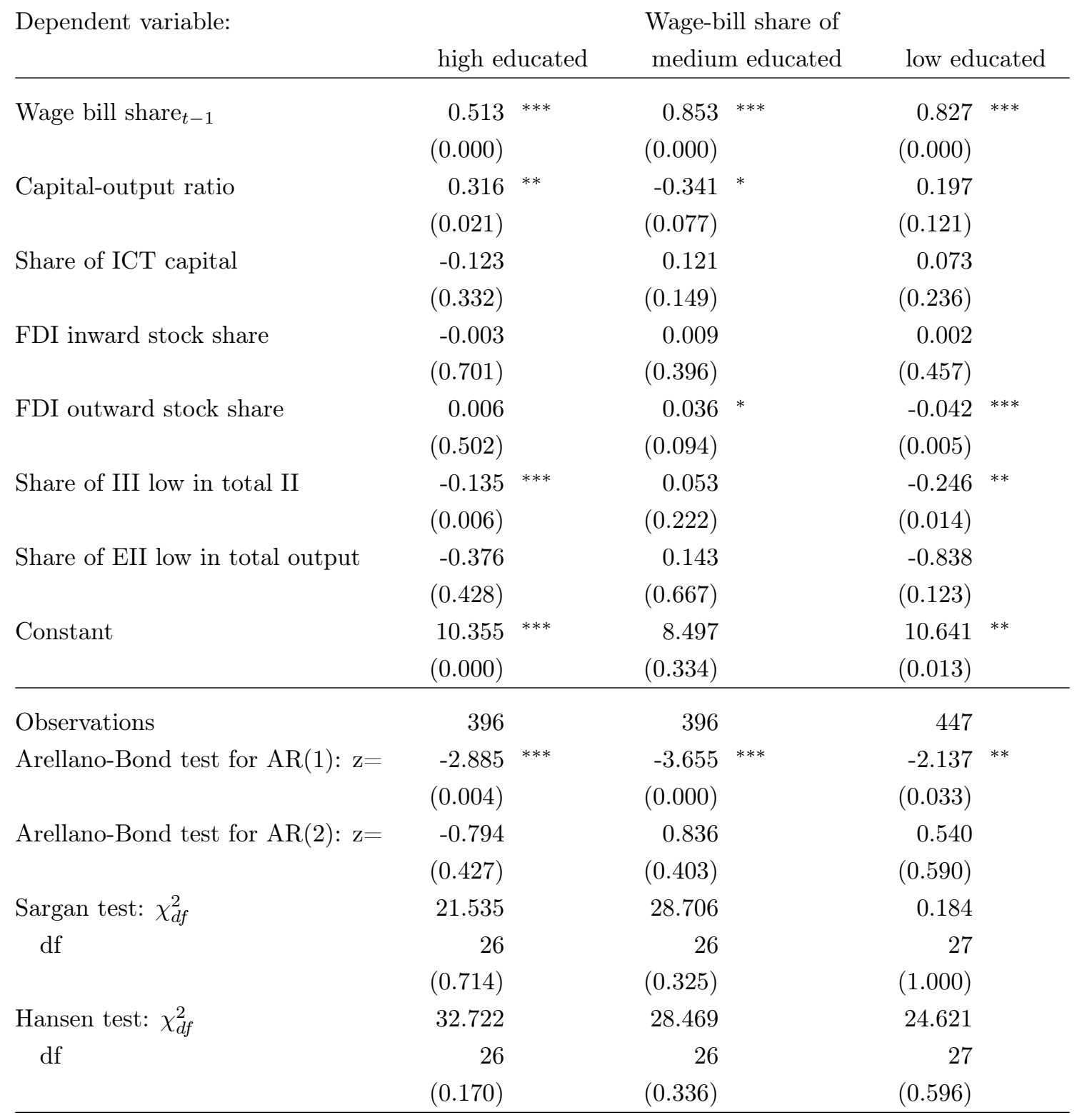

Table 2: Specification 2: Western European countries 


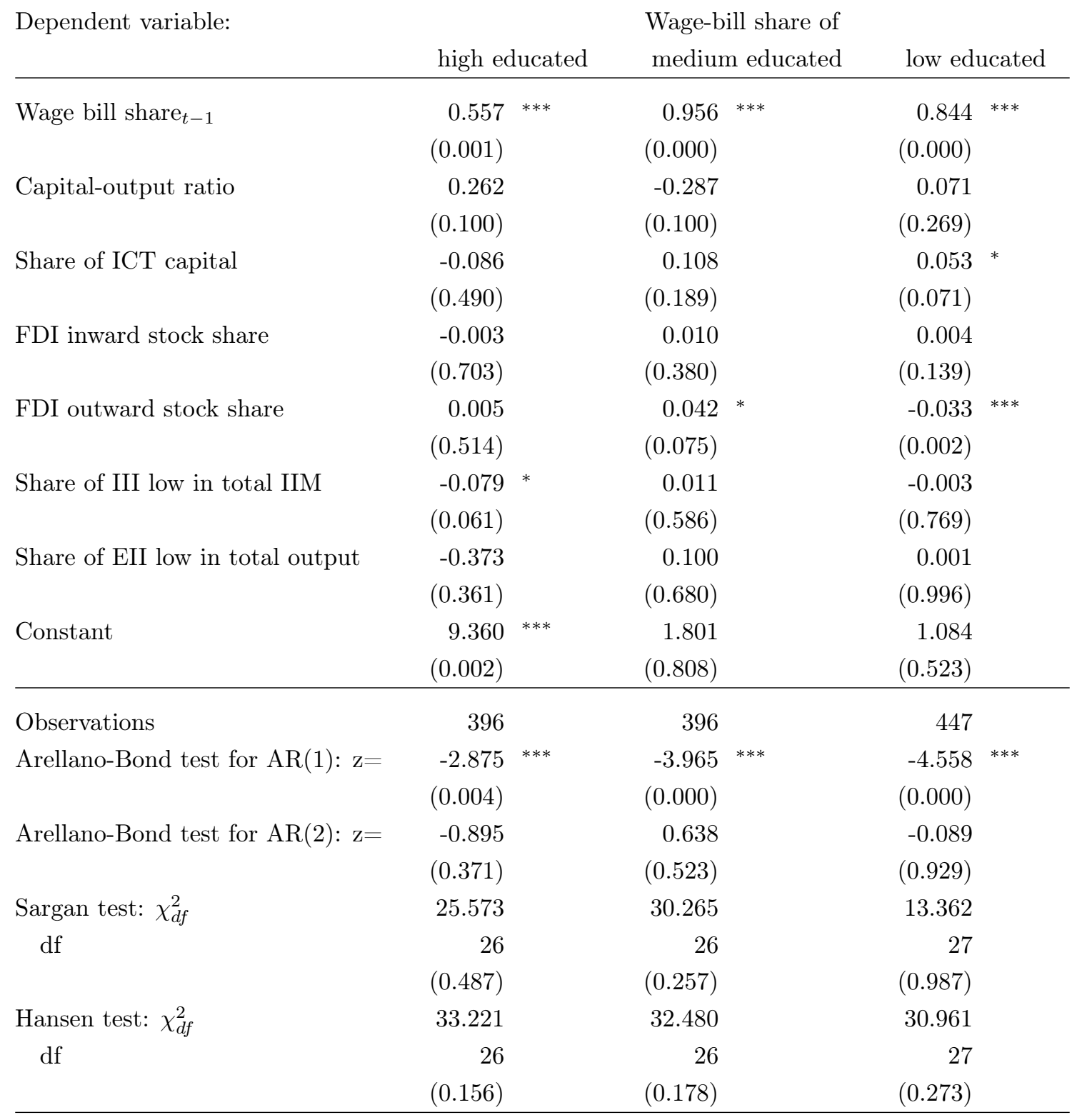

Table 3: Specification 3: Western European countries 
The capital-output ratio is positive and significant at $5 \%$ for the high-educated in specifications 1 and 2 . In these cases the capital stock exerts a negative, but significant only at $10 \%$ level, on the medium-educated. The coefficient is extremely high, above 0.3 , implying a long run impact of a $1 \%$ increase in the capital output ratio of -2.3 for the medium-educated and 0.7 for the high-educated. The share of ICT capital has no effect on the wage bill shares (it is positive and significant at the $10 \%$ level for the low-educated in the third specification only).

The outward FDI stock exerts a negative and highly significant impact on the low-educated and positive, although only significant at $10 \%$ level, for the medium-educated. There is no significant effect on the wage bill share of the high-educated persons. With respect to the FDI inward stock in the Western European economies there was no effect whatsoever. According to Table 1 a $10 \%$ increase in the outward-FDI-to-output ratio reduces the wage bill share of the low-educated by $0.42 \%$ and raises that of the medium-educated by $0.35 \%$. The long-run effect of the same increase in FDI, given by $\alpha_{i} / 1-\rho$, is -2.82 and 2.38 respectively.

Next let us turn to the measures of outsourcing. The share of intermediates imports to lowwage countries in output (Table 1 and in intermediate inputs to low-wage countries (Table 2 are negative and significant for both the high- and low-educated. In both cases the result is moreor-less confirmed in the three specifications although in the last specification (Table 3) the effect on the low-educated becomes insignificant. Outward outsourcing (i.e. exports of intermediate products) is never significant. The higher impact is exerted by the III to output ratio, with a coefficient of -0.31 for the low-educated and -.2 for the high-educated. The short-run effect of the share of III on total II is lower, -0.25 and -0.13 respectively, and even smaller (and significant only at $10 \%$ level) in the case of the coefficient of the third measure. The negative effect on the high-educated, although counter-intuitive, could indicate an indirect effect in favor of the medium-educated, while the negative effect on the lower-educated is consistent with a (medium) skill-biased impact of outsourcing.

Summing up, the results for Western European countries are more or less in line with the theoretical predictions. The capital-output ratio requires more high-skilled workers and less medium-skilled ones thus implying a capital-skill complementarity. However we could not find a significant effect of the share of ICT capital. The effects of the outward FDI is to increase the relative demand for the medium-educated domestically, while reducing the relative demand for the low-educated. This effect is amplified by the imported intermediates from low-income countries implying less high- and low-skilled labor to the advantage of the medium-skilled. This suggests that outsourcing to low-income countries consists of low-skill-intensive stages of production which allows Western European countries to rise the average skill level of domestic production. 


\section{$5 \quad$ Results for Central and Eastern European countries}

The results for the Central and Eastern European countries using specification (3.2) are shown in Tables 4 to 6 . The equation has been estimated using lags from three to five of the dependent variable and of kict; furthermore we used lags from three to six for kout and fdiis. All these instruments are collapsed into a single vector in order to save degrees of freedom and avoid over-identification problems. For the same reason we did not introduce the time dummies in the regression. Additional instruments are the inward and outward outsourcing measures and a set of time dummies. The former variables are assumed to be predetermined, hence they are valid instruments only for the equation in levels, while time dummies are exogenous and introduced in both equations.

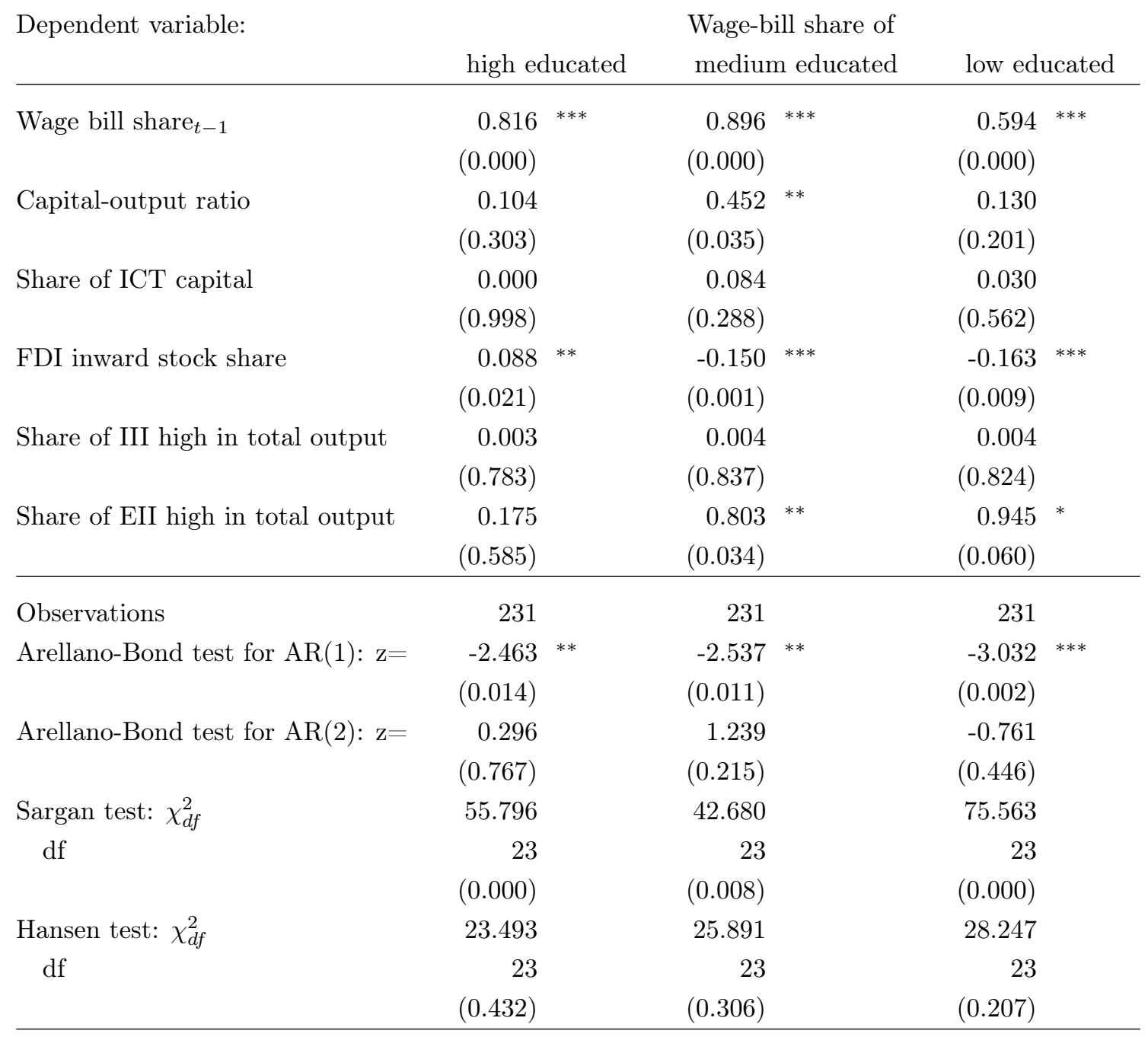

Table 4: Specification 1: Central and Eastern European countries 


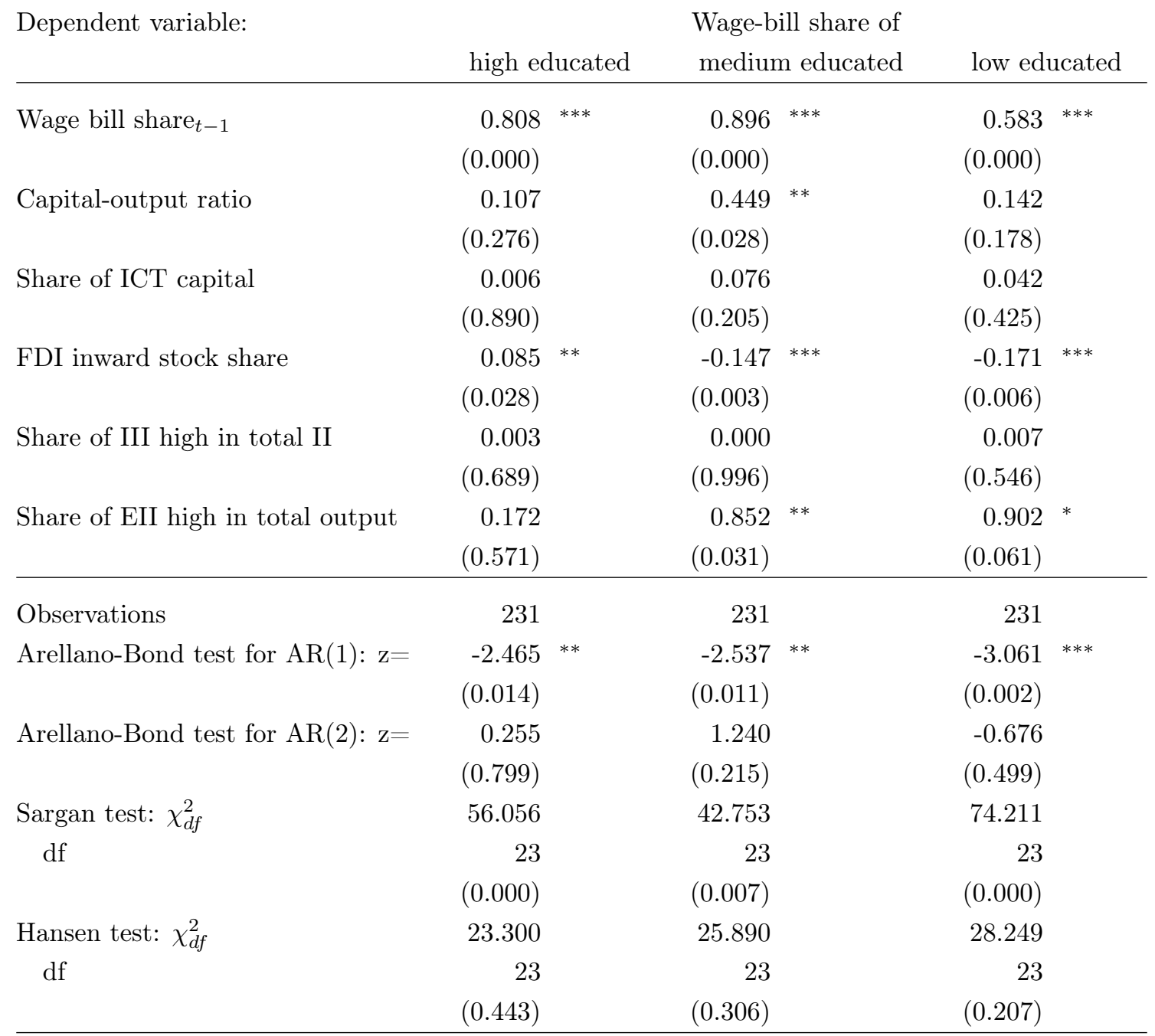

Table 5: Specification 2: Central and Eastern European countries 


\begin{tabular}{lccc} 
Dependent variable: & \multicolumn{3}{c}{ Wage-bill share of } \\
& high educated & medium educated & low educated \\
\hline Wage bill share $t-1$ & $0.815^{* * *}$ & $0.899^{* * *}$ & $0.588^{* * *}$ \\
& $(0.000)$ & $(0.000)$ & $(0.000)$ \\
Capital-output ratio & 0.098 & $0.428^{* *}$ & 0.132 \\
& $(0.347)$ & $(0.023)$ & $(0.174)$ \\
Share of ICT capital & 0.001 & 0.062 & 0.037 \\
& $(0.973)$ & $(0.303)$ & $(0.464)$ \\
FDI inward stock share & $0.085^{*}$ & $-0.136^{* * *}$ & $-0.172^{* * *}$ \\
& $(0.055)$ & $(0.010)$ & $(0.007)$ \\
Share of III high in total output & 0.001 & -0.004 & 0.004 \\
& $(0.916)$ & $(0.629)$ & $(0.618)$ \\
Share of EII high in total output & 0.188 & $0.901)^{* *}$ & 0.932 \\
& $(0.545)$ & $(0.012)$ & $(0.042)$ \\
\hline Observations & 231 & 231 & 231 \\
Arellano-Bond test for AR(1): z= & $-2.469 * *$ & -2.530 & -3.050 \\
& $(0.014)$ & $(0.011)$ & $(0.002)$ \\
Arellano-Bond test for AR(2): z= & 0.263 & 1.237 & -0.688 \\
Sargan test: $\chi_{d f}^{2}$ & $(0.792)$ & $(0.216)$ & $(0.491)$ \\
df & 56.005 & 42.986 & 73.758 \\
Hansen test: $\chi_{d f}^{2}$ & 23 & 23 & 23 \\
df & $(0.000)$ & $(0.007)$ & $(0.000)$ \\
& 23.492 & 26.021 & 28.247 \\
& 23 & 23 & 23 \\
& $(0.432)$ & $(0.300)$ & $(0.207)$ \\
\hline & & &
\end{tabular}

Table 6: Specification 3: Central and Eastern European countries 
The estimation performs well, with absence of second-order serial correlation and validity of the overidentifying restrictions, as shown by the Sargan and Hansen tests. The results are almost unchanged among the three specification, with none of the inward outsourcing measures (i.e. imports of intermediates) exerting a significant impact.

The other variables keep their signs and significance among the three specification, hence we refer only to the results of the specification reported in Table 4 for interpretation. The impact of the lagged dependent variable reveals a high persistence of the series, having a impact between 0.8 and 0.9 on both high and medium skilled and 0.6 on the low skilled. ${ }^{8}$

The capital-output ratio always has a positive impact, although it is significant and (relatively) strong only for the medium-skilled. In that group the impact of a $1 \%$ increase in the capital-output ratio is 0.05 in the short-run and 0.4 in the long-run, suggesting a strong complementarity between capital and medium-skilled labor. (Note that these medium-skilled workers include a number of technicians and related occupations.) The share of ICT capital has a positive impact too, but it is never significant.

The FDI inward stock in these countries exerts a significant impact on all three groups, with a positive impact on high-skilled workers and a negative one on both medium- and low-skilled. This is consistent with the assumption of a skill-biased impact of FDI in low-income countries. A $1 \%$ increase in the FDI-to-output ratio raises the wage bill share of the high-educated by $0.09 \%$ while reducing that of the medium- and low-educated by $0.15 \%$ and $0.16 \%$ respectively. The long-run effects of the same increase are, in the same order, $0.5,1.4$ and 0.4.

Finally, the export of intermediates to high-income countries (i.e. the imports of intermediates of the high-income countries) has a strong and positive impact on both the medium- and the low-skilled. In any case, for the latter group this variable is significant at the $5 \%$ level only in specification 3 (see Table 6). The short-run impact is above 0.8 for the medium-skilled and almost 0.95 for the low-skilled. This means that the long-run impact is 7.72 for the medium-skilled and 2.33 for the low-skilled.

In conclusion, the picture that arises from the estimations is pretty much in line with theoretical assumptions also for Central and Eastern European countries: FDI exerts a skill-biased impact by increasing the share of the high-skilled, and consequentially reducing those of other workers. The total capital stock favors the medium-skilled, which can mean that capital equipments require only particular skills mainly held by medium-educated workers, while a high education is required for foreign capital. The outsourcing process partially confirms the result from other studies, with a positive effect on the medium- and low-educated, suggesting a specialization into relatively low-skill-intensive products.

\footnotetext{
${ }^{8}$ The presence of a unit root problem is ruled out by the Levin-Lin test, which always rejects the assumption of non-stationarity of the wage bill share series.
} 


\section{Conclusions}

In this paper we analyzed the effects of high-tech capital, FDI flows and outsourcing on the wage bill shares in two groups of countries. These two groups are the Western European countries which are mainly seen as investors in the Eastern European countries (the second group) and importers of intermediate inputs. On the other hand, the second group consisting of Eastern European countries is mainly characterized by inflows of foreign direct investment and exports of intermediates. Our results are largely in line with prior expectations: In the Western European economies the FDI outward stock and imports of intermediates have negative effects on the wage bill share of the low-educated workers whereas FDI inward stocks and exports of intermediates have no significant effects at all. Surprisingly however, imports of intermediates also have a negative effect on the wage bill share of high-educated workers. This might be explained by a shift towards medium-educated workers. For the Eastern European countries the FDI inward stock shows negative effects on the wage bill share of medium- and low-educated workers and significantly positive effects for the high-educated workers. The exports of intermediates (note that these are mainly the imports of intermediates of the advanced Western European economies) show a positive effect on the wage bill share of the medium- and low-educated which relates to the expected pattern of specialization. An increase in capital services relative to output mainly favors high- and medium-educated workers in Western Europe and medium-educated workers in Central and Eastern Europe. We could not however find an additional effect of the share of ICT capital services in total capital services. Finally, the paper also points towards some problems with respect to measuring outsourcing and sensitivity of the results with regard to econometric specifications. This provides scope for future research. 


\section{References}

Anderson, R. and P. Brenton (1999). Outsourcing and low skilled workers in the UK. Bulletin of Economic Research (51), 267-286.

Arellano, M. and S. Bond (1991). Some tests of specification for panel data: Monte Carlo evidence and an application to employment equations. The Review of Economic Studies 58, $277-297$.

Arellano, M. and O. Bover (1995). Another look at the instrumental variable estimation of error-components models. Journal of Econometrics 68, 29-51.

Arndt, Sven, N. (1997). Globalisation and the open economy. North American Journal of Economics and Finance 8(1), 71-79.

Bruno, G., R. Crinó, and A. Falzoni (2004). Foreign direct investment, wage inequality and skilled labour demand in EU accession countries. CESPRI-WP 154.

Deardorff, Alan, V. (1998). Fragmentation in simple trade models. The University of Michigam, Research Seminars in International Economics, Discussion Paper (422).

Deardorff, Alan, V. (2001). Fragmentation across cones. In W. Arndt, S. and H. Kierzkowski (Eds.), Fragmentation and Internationa Trade. Oxford Unviersity Press, Oxford.

Egger, P. (2006). Intermediate goods trade and international wage convergence in central europe. Empirica (33), 181-192.

Egger, P. and R. Stehrer (2003). International outsourcing and skill-specific wage bill in Eastern Europe. The World Economy 26(1).

Esposito, P. (2007). Trade, outsourcing and skilled to unskilled wage bill ratio in CEECs. Discussion Paper, Dipartimento di Scienze Economiche. Sapienza, University of Rome. Forthcoming.

Esposito, P. and R. Stehrer (2007). The sector bias of skill biased technical change and the rising skill premium in transition economies. WIIW Working Paper (43).

Feenstra, R., C. and H. Hanson, G. (1996). Foreign investment, outsourcing and relative wages. In G. Feenstra and Irwin (Eds.), Political Economy of Trade Policy. MIT Press, Cambridge, Mass.

Feenstra, R., C. and H. Hanson, G. (1997). Foreign direct investment and relative wages: evidence from Mexico's maquiladoras. Journal of International Economics (42). 
Feenstra, R. and G. Hanson (1999). The impact of outsourcing and high technology capital on wages: Estimates for the United States, 1979-1990. Quarterly Journal of Economics 114, 907-940.

Geishecker, I. (2004). The skill bias of foreign direct investments in Central and Eastern Europe. Economic restructuring and labour markets in the Accession Countries. EU DG Employment, Social Affairs and Equal Opportunities.

Geishecker, I. (2006). Does outsourcing to Central and Eastern Europe really threaten manual workers' jobs in Germany? The World Economy 29(5), 559-583.

Helg, R. and L. Tajoli (2005). Patterns of international fragmentation of production and the relative demand for labor. North American Journal of Economics and Finance (16), 233-254.

Hijzen, A. (2007). International outsourcing, technological change and wage inequality. Review of International Economics 15(1), 188-205.

Hijzen, A., H. Görg, and R. Hine (2005, October). International outsourcing and the skill structure of labour demand in the United Kingdom. The Economic Journal 105, 860-878.

Jones, R. and H. Kierzkowski (1990). The role of services in production and international trade. In R. Jones and A. Krueger (Eds.), The Political Economy of International Trade. Basil Blackwell, Oxford.

Jones, R. and H. Kierzkowski (2001). A framework for fragmentation. In W. Arndt, S. and H. Kierzkowski (Eds.), Fragmentation and international trade. Oxford University Press, Oxford.

Kaminski, B. and F. Ng (2005). Production disintegration and integration of Central Europe into global markets. International Journal of Economics and Finance (14), 377-390.

Kertesi, G. and J. Köllö (2002). Labour demand with heterogenous labour inputs after the transition process in Hungary, 1992-1999. Budapest Working Papers on the Labour Market (2002/5).

Kohler, W. (2001). A specific factor view on outsourcing. North American Journal of Economics and Finance (12), 31-53.

Kohler, W. (2004, March). Inetrnational outsourcing and factor prices with multistage production. Economic Journal 114(494).

Lorentowicz, A., D. Marin, and A. Raubold (2005). Is human capital losing from outsourcing? Evidence for Austria and Poland. CESifo Working Paper 1616, Dec.. 
Marin, D. (2004). A nation of peots and thinkers - less so with Eastern enlargment? Austria and Germany. CEPR discussion paper 3526.

Marin, D. (2006). A new international division of labour in Europe: Outsourcing and offshoring to Eastern Europe. Journal of the European Economic Association 4(2-3), 612-622.

Skuratowicz, A. (2001). Effects of FDI on wage inequalities in Poland. Theory and evidence. In A. Skuratowicz (Ed.), FDI and Labour Markets in Central Europe. Effects of EU Enlargement. Interim Report, Phare ACE Scholarship P98-2030-R, KU Leuven.

Windmeijer, F. (2005). A finite sample correction for the variance of linear efficient two-step GMM estimator. Journal of Econometrics 126, 25-51. 


\title{
Short list of the most recent wiiw publications (as of March 2009)
}

For current updates and summaries see also wiiw's website at www.wiiw.ac.at

\section{Effects of High-Tech Capital, FDI and Outsourcing on Demand for Skills in West and East} by Piero Esposito and Robert Stehrer

wiiw Working Papers, No. 51, March 2009

21 pages including 6 Tables

hardcopy: EUR 8.00 (PDF: free download from wiiw's website)

\author{
wiiw Monthly Report 3/09 \\ edited by Leon Podkaminer \\ - Euro or not? Early lessons from the crisis \\ - Migration from the New to the Old EU Member States: country experiences \\ - Outsourcing and skills: an empirical investigation \\ - Statistical Annex: Selected monthly data on the economic situation in Southeast Europe, Russia \\ and Ukraine \\ wiiw, March 2009 \\ 32 pages including 10 Tables and 9 Figures \\ (exclusively for subscribers to the wiiw Service Package)
}

\section{Cross-Border Trade and FDI in Services}

by Carmen Fillat-Castejón, Joseph F. Francois and Julia Wörz

wiiw Working Papers, No. 50, February 2009

49 pages including 15 Tables and 3 Figures

hardcopy: EUR 8.00 (PDF: free download from wiiw's website)

\section{Differentiated Impact of the Global Crisis \\ by Vladimir Gligorov, Gábor Hunya, Josef Pöschl et al.}

wiiw Current Analyses and Forecasts. Economic Prospects for Central, East and Southeast Europe, No. 3, February 2009

137 pages including 40 Tables and 16 Figures

hardcopy: EUR 70.00 (PDF: EUR 65.00)

\section{wiiw Monthly Report 2/09}

edited by Leon Podkaminer

- The Republic of Moldova: short-lived recovery

- Patterns of international trade diversification in the transition economies

- Some reflections on the reform of the international financial architecture

- Statistical Annex: Selected monthly data on the economic situation in Central and Eastern Europe (tables)

wiiw, December 2009

34 pages including 12 Tables and 2 Figures

(exclusively for subscribers to the wiiw Service Package) 


\title{
Entwicklungen der Weltwirtschaft im Kontext der Finanzmarktkrise \\ by Michael Landesmann und Roman Stöllinger
}

wiiw Research Papers in German language, January 2009

(reprinted from: Österreichs Außenwirtschaft 2008, commissioned by the Austrian Federal Ministry

of Economics and Labour (BMWA) in the framework of the Research Centre International

Economics (FIW) and funded under the internationalization programme 'go international')

22 pages including 6 Figures

hardcopy: EUR 8.00 (PDF: free download from wiiw's website)

\author{
wiiw Monthly Report $1 / 09$ \\ edited by Leon Podkaminer \\ - The Chinese automotive industry in a global context \\ - Index of global tolerance: a quantitative analysis based on 'World Values Survey' data \\ - Some reflections on the crisis management in the EU \\ - Statistical Annex: Selected monthly data on the economic situation in Southeast Europe, Russia \\ and Ukraine (tables) \\ wiiw, January 2009 \\ 30 pages including 14 Tables \\ (exclusively for subscribers to the wiiw Service Package)
}

\section{Western Balkan Countries: Adjustment Capacity to External Shocks, with a Focus on Labour Markets}

by Vladimir Gligorov, Anna lara, Michael Landesmann, Robert Stehrer and Hermine Vidovic

\author{
wiiw Research Reports, No. 352, December 2008 \\ 136 pages including 35 Tables and 40 Figures \\ hardcopy: EUR 8.00 (PDF: free download from wiiw's website)
}

\section{Migration and Commuting Propensity in the New EU Member States}

by Anna lara, Michael Landesmann, Sebastian Leitner, Leon Podkaminer, Roman Römisch and Hermine Vidovic

wiiw Research Reports, No. 351, December 2008

106 pages including 21 Tables, 16 Figures and 5 Maps

hardcopy: EUR 22.00 (PDF: EUR 20.00)

\section{Real Convergence and Inflation: Long-Term Tendency vs. Short-Term Performance}

by Leon Podkaminer

wiiw Working Papers, No. 49, December 2008

17 pages including 4 Tables and 6 Figures

hardcopy: EUR 8.00 (PDF: free download from wiiw's website)

\section{International Trade and Economic Diversification: \\ Patterns and Policies in the Transition Economies \\ by Michael Landesmann}

wiiw Research Reports, No. 350, December 2008

87 pages including 17 Tables and 18 Figures

hardcopy: EUR 22.00 (PDF: EUR 20.00) 
wiiw Monthly Report 12/08

edited by Leon Podkaminer

- Albania: the importance of being aside

- Bosnia and Herzegovina: suffering from unfavourable constellations

- Kazakhstan: commodity price decline aggravates crisis

- Kosovo: risks to recovery

- Montenegro: budget to the rescue

- Serbia: risking recession

- Statistics: Minimum interest rates, nominal exchange rates and real appreciation in Central, East and Southeast Europe, 2005-2008 (cross-country graphics)

wiiw, December 2008

24 pages including 5 Tables and 9 Figures

(exclusively for subscribers to the wiiw Service Package)

\section{wiiw Monthly Report 11/08}

edited by Leon Podkaminer

- Russia in the global financial storm

- Ukraine: 'hard landing' in sight

- Croatia: slowing economy

- Macedonia: external balances worsen

- Turkey's nerves of steel

- Statistics: Consumer and producer prices; employees and unemployment in Central, East and Southeast Europe, 2003-2008 (graphics)

wiiw, November 2008

28 pages including 6 Tables and 10 Figures

(exclusively for subscribers to the wiiw Service Package)

\section{The Role of Public Policy in Closing Foreign Direct Investment Gaps: An Empirical Analysis} by Christian Bellak, Markus Leibrecht and Robert Stehrer

wiiw Working Papers, No. 48, October 2008

23 pages including 8 Tables

hardcopy: EUR 8.00 (PDF: free download from wiiw's website)

\section{wiiw Monthly Report 10/08}

edited by Leon Podkaminer

- Bulgaria: can the boom hold on, and for how long?

- The Czech Republic: weak domestic demand, resilient exports, sound banking

- Hungary: outlook reconsidered

- Poland: a slowdown in the making

- Romania: record economic growth (

- Slovakia: backed by continued robust growth towards the eurozone

- Slovenia: signs of weakness

- Statistics: Selected monthly data on the economic situation in Central, East and Southeast Europe, 2007-2008

wiiw, October 2008

36 pages including 17 Tables

(exclusively for subscribers to the wiiw Service Package) 


\section{wiiw Service Package}

The Vienna Institute offers to firms and institutions interested in unbiased and up-to-date information on Central, East and Southeast European markets a package of exclusive services and preferential access to its publications and research findings, on the basis of a subscription at an annual fee of EUR 2,000.

This subscription fee entitles to the following package of Special Services:

- A free invitation to the Vienna Institute's Spring Seminar, a whole-day event at the end of March, devoted to compelling topics in the economic transformation of the Central and East European region (for subscribers to the wiiw Service Package only).

- Copies of, or online access to, The Vienna Institute Monthly Report, a periodical consisting of timely articles summarizing and interpreting the latest economic developments in Central and Eastern Europe and the former Soviet Union. The statistical annex to each Monthly Report contains, alternately, country-specific tables or graphs with monthly key economic indicators, economic forecasts, the latest data from the wiiw Industrial Database and excerpts from the wiiw FDI Database. This periodical is not for sale, it can only be obtained in the framework of the wiiw Service Package.

- Free copies of the Institute's Research Reports (including Reprints), Current Analyses and Forecasts, Country Profiles and Statistical Reports.

- A free copy of the wiiw Handbook of Statistics (published in October/November each year and containing more than 400 tables and graphs on the economies of Albania, Bosnia and Herzegovina, Bulgaria, Croatia, the Czech Republic, Estonia, Hungary, Latvia, Lithuania, Macedonia, Montenegro, Poland, Romania, Russia, Serbia, the Slovak Republic, Slovenia and Ukraine)

- Free online access to the wiiw Monthly Database, containing more than 1200 leading indicators monitoring the latest key economic developments in ten Central and East European countries.

- Consulting. The Vienna Institute is pleased to advise subscribers on questions concerning the East European economies or East-West economic relations if the required background research has already been undertaken by the Institute. We regret we have to charge extra for ad hoc research.

- Free access to the Institute's specialized economics library and documentation facilities.

Subscribers who wish to purchase wiiw data sets on CD-ROM or special publications not included in the wiiw Service Package are granted considerable price reductions.

For detailed information about the wiiw Service Package please visit wiiw's website at www.wiiw.ac.at 
The Vienna Institute

for International Economic Studies

Rahlgasse 3

A-1060 Vienna

O Please forward more detailed information about the Vienna Institute's Service Package

O Please forward a complete list of the Vienna Institute's publications to the following address

Please enter me for

O 1 yearly subscription of Research Reports (including Reprints)

at a price of EUR 225.00 (within Austria), EUR 250.00 (Europe) and EUR 265.00 (overseas) respectively

Please forward

O the following issue of Research Reports

0 the following issue of Current Analyses and Forecasts

O the following issue of Country Profiles

$\bigcirc$ the following issue of Working Papers

O the following issue of Statistical Reports

0 the following issue of Research Papers in German language

O the following issue of wiiw Database on Foreign Direct Investment

O the following issue of wiiw Handbook of Statistics

Name

Address

Telephone

Fax

E-mail

Date

Signature

Herausgeber, Verleger, Eigentümer und Hersteller:

Verein „Wiener Institut für Internationale Wirtschaftsvergleiche“ (wiiw),

Wien 6, Rahlgasse 3

Postanschrift: $\quad$ A-1060 Wien, Rahlgasse 3, Tel: [+431] 53366 10, Telefax: [+431] 533661050

Internet Homepage: www.wiiw.ac.at

Nachdruck nur auszugsweise und mit genauer Quellenangabe gestattet.

P.b.b. Verlagspostamt 1010 Wien 